\title{
MODIFIED PASSIVE ATMOSPHERE IN POST-HARVEST MANGABA FRUIT CONSERVATION IN THREE MATURITY DEGREES
}

Flávia Aparecida de Carvalho Mariano-Nasser ${ }^{1}$, Aparecida Conceição Boliani ${ }^{2}$, Maurício Dominguez Nasser ${ }^{3}$, Heloiza Ferreira Alves-Prado ${ }^{2}$, Maximiliano Kawahata Pagliarini ${ }^{4}$, Erica Rodrigues Moreira ${ }^{5}$

${ }^{1}$ Universidade Estadual Paulista - UNESP, Faculdade de Ciências Agronômicas, Pós-doutorado em Horticultura, Botucatu, SP. ${ }^{2}$ Universidade Estadual Paulista - UNESP, Docente do Departamento de Fitotecnia, Tecnologia de Alimentos e Sócio economia, Ilha Solteira, SP. ${ }^{3}$ Pesquisador Científico da Agência Paulista de Tecnologia dos Agronegócios - APTA - Polo Regional Alta Paulista, Adamantina, SP. ${ }^{4}$ Universidade Federal da Grande Dourados, Faculdade de Ciências Agrárias, Dourados, MS. ${ }^{5}$ Doutora em Agronomia. E-mail: $\underline{\text { mdnasser@apta.sp.gov.br }}$

\begin{abstract}
Mangaba fruits are highly perishable, presenting short shelf life, rapid maturation and delicate and fragile bark, making it difficult to commercialize over long distances.Objective of this study was to evaluate the best harvest maturity degree as well as the most suitable modified atmosphere for post-harvest quality preservation.Mangaba fruits maturity degrees were: green, middle-mature and mature; and packed in three types of modified atmosphere: polyethylene terephthalate - PET; expanded polystyrene tray with polyvinyl chloride film (PVC) and low density polyethylene (LDPE) packaging with lid. In each evaluation were analysed: loss of fresh mass, firmness, ascorbic acid, soluble solids, titratable acidity, $\mathrm{pH}$ and reducing sugars. Falling (mature) mangabas limit the storage period in 6 days, regardless modified atmosphere used, presenting greater loss of mass(2.,39 a 2.91\%), reducing sugar (4.05 a 4.58\%) content and less firmness $(0,98$ a 1,47 $\mathrm{N})$. These fruits must be destined to processing, in order to add value to the product.Mangabas harvested in middle-mature stage conditioned in polyethylene tray with PVC stored at a temperature $3^{\circ} \mathrm{C} \pm 1$ and $80 \% \pm 1$ $\mathrm{RU}$ maintains ascorbic acid contents during the storage period.

Key words: HancorniaspeciosaGomes; packing; storage.

\section{ATMOSFERA MODIFICADA PASSIVA NA CONSERVAÇÃO PÓS-COLHEITA DE MANGABA EM TRÊS GRAUS DE MATURAÇÃO}

\section{RESUMO}

Os frutos da mangabeira são altamente perecíveis, apresentando vida de prateleira curta, maturação rápida e casca delicada e frágil, dificultando sua comercialização a longas distâncias.Objetivou-se avaliar o melhor grau de maturação para colheita assim como a atmosfera modificada mais adequada para a conservação da qualidade pós-colheita da mangaba.Foram utilizados frutos de mangaba nos estádios verde, de vez e maduro; e acondicionadas em três tipos de atmosfera modificada: polietileno tereftalato - PET, bandeja de poliestireno expandido, com filme de cloreto de polivinila (PVC) e embalagem de polietileno de baixa densidade (PEBD) com fechamento.A cada retirada foram analisadas:perda de massa fresca, firmeza, ácido ascórbico, sólidos solúveis, acidez titulável, $\mathrm{pH}$ e açúcares redutores.Mangabas de caída ou maduras limitam até 6 dias o período de armazenamento, independente da atmosfera modificada utilizada, apresentando maior perda de massa (2,39 a 2,91\%),teor de açúcar redutor $(4,05$ a 4,58\%) e menor firmeza $(0,98$ a 1,47 $\mathrm{N})$.Esses frutos devem ser destinados ao processamento, de modo a agregar valor ao produto.Mangabas colhidas no estádio de vez acondicionadas em bandeja de polietileno com PVC armazenadas em temperatura de $3^{\circ} \mathrm{C} \pm 1$ e $80 \% \pm 1$ UR mantém teores de ácido ascórbico no período de armazenamento.

Palavras-chave:armazenamento; embalagem; HancorniaspeciosaGomes.

\section{INTRODUCTION}

The mangaba tree (Hancorniaspeciosa Gomes) belongs to Apocynaceae family, produces berry type fruits, and presents climacteric behaviour and high metabolic activity. When physiologically mature the fruit detaches itself from plant and falls to the ground(LEDERMAN et al., 2000;MOURA, 2005; SANTOS et al., 2009). 
Mangaba is rich in iron, phenolic compounds (tannins), presents great antioxidant potential and high levels of vitamin C, an important trait whereas human body does not synthesize this vitamin. The fruit exhibits an extraordinary flavour and aroma, besides presenting low caloric value (43 to $60 \mathrm{Kcal}$ ), being widely used by Northeast Statesfood industries (SILVA JUNIOR, 2004; CHITARRA; CHITARRA, 2005; PEREIRA et al., 2006; CARNELOSSI et al., 2009;ALMEIDA et al., 2011).

The maturity degree during harvest time is one of the main determinants of chemical composition and nutritional value, especially in climacteric fruits. Immature harvested fruits are more prone to wrinkling and mechanical damage, in addition to exhibit inferior flavour and aroma when they are mature. However if they are harvested much matured, they become very soft, losing flavour as soon as harvested and in both situations fruits become more susceptible to physiological disorders(CHITARRA; CHITARRA, 2005).

Carnelossi et al. (2004) reportedsuccess of tropical fruits commercialization is directly related to their adequate storage. Modification in atmosphere aims to decrease the metabolism of conditioned product, reducing oxygen levels and raising carbon dioxide content to increase storage period and consequently commercialization (VIEITES et al., 2014; STEFFENS et al., 2009).

Mangaba fruits are highly perishable, presenting short shelf-life, rapid maturation and delicate and fragile bark, making it difficult to commercialize over long distances. In Brazilian Cerrado region, trees present short period of harvest and alternation of production (PEREIRA et al., 2006), which makes necessary to know postharvest physiology in order to obtaining technical information that contributes to increase fruit storage without altering physical, sensorial and nutritional characteristics(DREHMER; AMARANTE, 2008).

The objective of this study was to evaluate the best harvest maturity degree as well as the most suitable modified atmosphere for postharvest quality preservation.

\section{MATERIAL AND METHODS}

The experiment was conductedat Food Technology Laboratory, located at UniversidadeEstadualPaulista "Júlio de MesquitaFilho" (UNESP), Campus ofllhaSolteira $\mathrm{SP}$, with mangaba fruits produced at Farm of Teaching, Research and Extension (UNESP).
Fruits in green, middle-mature and mature maturity stages were used. Green and middlemature fruits were classified subjectively by colour of epidermis (green: green epidermis and middlemature: greenish yellow epidermis) and firmness (green: hard and middle-mature: slightly hard). Fruits were conditioned in plastic boxes and sent to laboratory where they were selected for lothomogenization. Afterwards, they were washed and sanitized with sodium hypochlorite $\left(10 \mathrm{mg} \mathrm{L}^{-1}\right)$ for 10 minutes, drained and air-dried for experiment assembly (VIEIRA et al., 2010; NARAIN; FERREIRA, 2003; PEREIRA et al., 2006).

All selected fruits were divided in three groups (maturity degrees) and conditioned in three types of modified atmosphere: polyethylene terephthalate package (PET), expanded polystyrene tray $(18 \mathrm{~cm} \times 12.5 \mathrm{~cm} \times 4 \mathrm{~cm})$ covered with12 $\mu \mathrm{m}$ polyvinyl chloride film (PVC) and low density polyethylene (LDPE) package with lid (18 $\mathrm{cm} \times 23 \mathrm{~cm}, 0.1 \mathrm{~mm}$ of thickness). Each experimental unit had300 g, approximately, and package in B.O.D. storage at $3{ }^{\circ} \mathrm{C} \pm$ 1.00 temperatureand $80 \% \pm 1.00$ relative humidity for six days.

The used temperature was the result of a preliminary test before the implantation of this experiment, in which different controlled temperatures (in B.O.D.) were tested: $3{ }^{\circ} \mathrm{C} \pm 1.00$; $8{ }^{\circ} \mathrm{C} \pm 1.00$ and room temperature $\left(26^{\circ} \mathrm{C} \pm 1.00\right)$, with $80 \% \pm 1.00$ (temperature $3{ }^{\circ} \mathrm{C}$ and $8{ }^{\circ} \mathrm{C}$ ) and $50 \% \pm 7.00$ (ambient) relative humidity. Although it was a tropical fruit, mangaba showed better conservation at $3{ }^{\circ} \mathrm{C} \pm 1.00$ without presenting cold damagesymptoms (chilling), as expected with low temperature conservation.Probably the exposure period (six days) was not sufficient for development of these phenomena. The storage period was reduced to six days due to loss of mature fruits treatments.

The treatments were: $\mathrm{T} 1=$ green fruits in low density polyethylene packaging with lid $(\mathrm{LDPE}) ; \mathrm{T} 2=$ green fruits inpolyethylene terephthalate package (PET); $\mathrm{T3}=$ green fruits inexpanded polystyrene tray covered with polyvinyl chloride film (EP-PVC); T4 = middlemature fruits in LDPE; T5 = middle-mature fruits in PET; $\mathrm{T6}=$ middle-mature fruits in EP-PVC; $\mathrm{T7}=$ mature fruits in LDPE; T8 = mature fruits in PET; T9 $=$ mature fruits in EP-PVC.

The experimental design was completely randomized, in a $9 \times 3$ factorial scheme (treatments $x$ evaluation periods - implantation day, three and six days), with two replicates per treatment. According to Pimentel Gomes (2009), it 
is important to consider a number of repetitions in order to have at least 10 degrees of freedom for residue, therefore for this research two replicates were used (residue degrees of freedom $=26$ ) (Table 1).

At each evaluation were analysed: fresh mass loss, firmness, ascorbic acid, soluble solids, titratable acidity, maturity index, $\mathrm{pH}$ and reducing sugars. The mass loss was calculated from mass differences of experimental unitsandinitial fruit mass as reference, using precision scale Marte ${ }^{\circledR}$ AS 5500 and results expressed in percentage (\%). Fruit firmness was measured using manual penetrometer determined in two distinct points (central and apexregions) in each fruit.

Ascorbic acid contents were determined by titration, and the results expressed as $\mathrm{mg}$ of ascorbic acid $100 \mathrm{~g}^{-1}$ of pulp. Soluble solids determination were performed by direct reading on a table refractometer VEB Carl Zeiss Jenz- DDR', with temperature correction to $20{ }^{\circ} \mathrm{C}$, expressing the results in ${ }^{\circ} \mathrm{Brix}$. The titratable acidity was obtained by titration with $0.01 \mathrm{~N} \mathrm{NaOH}$ solution and phenolphthalein indicator and results expressed in $\mathrm{g}$ of citric acid $100 \mathrm{~g}^{-1}$ of pulp.Maturity index was calculated by the ratio between soluble solid and titratable acidity contents. The $\mathrm{pH}$ was performed in the mangaba fruit pulp, using digital potentiometer modelDMPH-2 Digimed. Reducing sugar content was determined by Lane-Eynon method and results expressed in percentage of glucose. All chemical and physico-chemical traits were analysed according toAdolfoLutz Institute (1985) methodologies.
Data were submitted to analysis of variance and means were compared by Tukey test at $5 \%$ of probability. The mass loss data were transformed by $V(x+1 / 2)$, but in Table 2 the original data were used.

\section{RESULTS AND DISCUSSION}

At Table 1 it was possible to note mass loss, firmness, ascorbic acid content, soluble solids, titratable acidity, maturity index, $\mathrm{pH}$ and reducing sugar were significantly influenced by treatments. In storage period and interaction (treatment $x$ time), there was significance for loss of mass, firmness, ascorbic acid, soluble solids, titratable acidity, maturity index and reducing sugar.

The mass loss was influenced by treatment ( $p<0.01$ - Table 1) and the largest mass losses were observed in six-days-storage fruits, mature stage inpolyethylene terephthalate package (PET) (2.91\%) (Table 2). However, in low density polyethylene packaging with lid (LDPE) and expanded polystyrene tray covered with polyvinyl chloride film (EP-PVC) did not also differ statistically, with loss of $2.39 \%$ and $2.47 \%$, respectively. In the other hand, lower mass losses were noticed for green fruits in LDPE $(0.06 \%)$ and middle-mature fruits in LDPE $(0.14 \%)$ (Table 2). The highest losses in mature fruits (fallen fruits) are possibly related to loss of solutes due to high respiration caused by the fall. These losses cause fruits depreciation and limitedexperiment in six days. Three to $6 \%$ of fresh mass losses are sufficient to cause drop of quality in vegetables (CHITARRA; CHITARRA, 2005).

Table 1. Mean square values and significance levels for mangaba fruits evaluated traits in three maturity degrees in different modified atmosphere, storage at $3^{\circ} \mathrm{C} \pm 1.00$ and $80 \% \pm 1.00$ relative humidity for six days.Massloss data weretransformedby $\sqrt{ }(x+1 / 2)$.

\begin{tabular}{lccccc}
\hline Variation & $\mathrm{DF}$ & $\mathrm{ML}$ & $\mathrm{FF}$ & $\mathrm{AA}$ & $\mathrm{SS}$ \\
\hline Treatments & 8 & $0.227^{* *}$ & $14732.1^{* *}$ & $12038.7^{* *}$ & $16.8^{* *}$ \\
Time & 2 & $1.764^{* *}$ & $1431.9^{* *}$ & $42584.1^{* *}$ & $0.28^{* *}$ \\
Interaction & 16 & $0.077^{*}$ & $405.5^{* *}$ & $3146.5^{* *}$ & $2.78^{* *}$ \\
Residue & 26 & 0.035 & 137.9 & 539.0 & 0.82 \\
\hline Overall mean & - & 1.02 & 66.43 & 232.90 & 13.90 \\
\hline C.V. (\%) & - & 18.70 & 17.60 & 9.90 & 6.40 \\
\hline Variation & $\mathrm{DF}$ & $\mathrm{TA}$ & $\mathrm{Ml}$ & $\mathrm{pH}$ & $\mathrm{RS}$ \\
\hline Treatments & 8 & $0.167^{* *}$ & $110.8^{* *}$ & $0.06^{* *}$ & $8.09^{* *}$ \\
Time & 2 & $0.778^{* *}$ & $136.5^{* *}$ & $0.09^{* *}$ & $0.91^{* *}$ \\
Interaction & 16 & $0.078^{* *}$ & $8.51^{* *}$ & $0.01^{\text {ns }}$ & $0.18^{* *}$ \\
Residue & 26 & 0.001 & 2.48 & 0.01 & 0.02 \\
\hline Overall mean & - & 0.912 & 16.50 & 3.80 & 2.30 \\
\hline C.V. (\%) & - & 4.60 & 9.50 & 3.10 & 6.00 \\
\hline ** (p<0,01); ${ }^{*}(\mathrm{p}<0,05) ; \mathrm{ns}$ (not significant). C.V. (\%): Coefficient of experimental variation. ML: mass loss (\%), FF: fruit \\
firmness (Newton), AA: ascorbic acid (mg of ascorbic acid $100 \mathrm{~g}^{-1}$ of pulp); SS: soluble solid (oBrix); AT: titratable acidity (g \\
of citric acid 100 g ${ }^{-1}$ of pulp); MI: maturity indexeRS: reducing sugar (\%). & &
\end{tabular}


FigueiredoNeto et al. (2013) studying papaya cv. Formosa subjected to mechanical damage by injury, mentioned that fruits which suffered post-harvest impacts presented greater loss of solubles andmass. Opposite result was found by Santos et al. (2009), that studying mangabas in three maturity stages observed greater losses in green fruits compared to middlemature fruits.

Another factor that may have influenced mangabamass loss was package constituent material. It was generally knownthatmaterials havedifferent transmission intensity of water vapour and gas. According to Chitarra and Chitarra (2005) PVC film is classified as low water vapour barrier (8 $\left.\mathrm{g} \mathrm{m}^{-2} \mathrm{day}^{-1} \mathrm{~atm}^{-1}\right)$, while LDPE is considered as a high barrier $\left(4 \mathrm{~g} \mathrm{~m}^{-2} \mathrm{day}^{-1} \mathrm{~atm}^{-1}\right)$.

Fruit storage increased fresh mass loss during evaluated period $(p<0.01-$ Table 1$)$ and influenced significantly green and middlematurestagesin EP-PVC treatment and mature fruits in all packages. This behaviour corroborates with Santos et al. (2009) and Campos et al. (2011), which working with storage mangaba observed increase of fresh mass loss during storage period. There was no influence ( $p>0.05)$ on green and middle-mature fruits packed in LDPE and PET. These modified atmospheres present a greater barrier against gas exchange and loss of water to the environment, probably this characteristic may have contributed to this lower loss (moisture retention inside the package). Simón et al. (2008) cited that mass loss is due to water loss by transpiration and evaporation of stored product which is directly influenced by package water vapour transmission rate.

Table 2. Mangaba fruits mass loss (\%) in three maturity degrees under different modified atmospheres,storage at $3^{\circ} \mathrm{C} \pm 1.00$ and $80 \% \pm 1.00$ relative humidity for six days.Massloss data weretransformedby $(x+1 / 2)$.

\begin{tabular}{|c|c|c|c|c|c|c|c|c|c|}
\hline \multirow[t]{3}{*}{ Maturity degrees } & \multirow[t]{2}{*}{ Packages } & \multicolumn{7}{|c|}{ Storage period (days) } & \multirow{2}{*}{ Mean } \\
\hline & & \multicolumn{2}{|c|}{0} & \multicolumn{2}{|l|}{3} & \multicolumn{3}{|c|}{6} & \\
\hline & LDPE & 0 & $\mathrm{aA}$ & 0.03 & a $A$ & 0.06 & c & $\mathrm{A}$ & 0.03 \\
\hline \multirow[t]{3}{*}{ Green } & PET & 0 & a $A$ & 0.53 & a $\mathrm{A}$ & 0.84 & bc & A & 0.45 \\
\hline & EP-PVC & 0 & a $B$ & 0.65 & a $A B$ & 1.49 & $a b c$ & A & 0.71 \\
\hline & LDPE & 0 & a $\mathrm{A}$ & 0.03 & a A & 0.14 & c & A & 0.06 \\
\hline \multirow[t]{3}{*}{ Middle-mature } & PET & 0 & a $\mathrm{A}$ & 0.44 & a $A$ & 1.15 & $a b c$ & A & 0.53 \\
\hline & EP-PVC & 0 & a $B$ & 0.74 & a B & 1.58 & $a b c$ & A & 0.77 \\
\hline & LDPE & 0 & a $B$ & 0.21 & $\mathrm{a} B$ & 2.39 & $a b$ & A & 0.87 \\
\hline \multirow[t]{2}{*}{ Mature } & PET & 0 & a $B$ & 1.44 & a B & 2.91 & a & A & 1.45 \\
\hline & EP-PVC & 0 & a $B$ & 1.15 & $\mathrm{a} B$ & 2.47 & $a b$ & A & 1.21 \\
\hline
\end{tabular}

Means followed by the same letter, uppercase in the line and lowercase in the column, do not differ significantly from each other at $95 \%$ probability, by the Tukey test. LDPE: low density polyethylene package with lid. PET: polyethylene terephthalate package. EP-PVC: expanded polystyrene tray covered with $12 \mu \mathrm{m}$ polyvinyl chloride film.

Mangaba firmness mean values (Table 3 ) were significant among treatments $(p<0.01)$, with the highest firmness observed in green stage conditioned in LDPE (121.1 N) at sixth day of storage, however, not statistically different in relation to green stage in PET $(88.7 \mathrm{~N})$, green and middle-matudein EP-PVC $(104.9 \mathrm{~N}$ and $91.6 \mathrm{~N}$, respectively).

It is known firmness loss is a particularity of fruit ripening process. Its measurement on fruit shows changes in cellular structure due to biochemical transformations, responsible for texture, furthermore, it is considered as quality attribute and with other traits is used for evaluating products shelf-life (CHITARRA;
CHITARRA, 2005). Perfeito et al. (2015) cited that firmness might be used as an attribute to indicate mangabamaturity degree, as there is a significant difference between fruit firmness of middlemature and those with advanced maturation, as in the present research.

In shelf-life period, there was a significant influence $(p<0.01)$ on treatments green in PET and middle-mature in all storages, in these atmospheres a decrease in firmness during storage was observed agreeingwith Silva et al. (2013) and Santos et al. (2009) who verified mangaba firmness decrease in relation to storage period and maturation degrees studied. They cited the 
difficulty in analysing firmness in falling fruits due to compromised texture of them.

Table 3. Mangaba fruit firmness $(\mathrm{N})$ in three maturity degreesunder different modified atmospheres, storage at $3^{\circ} \mathrm{C} \pm 1.00$ and $80 \% \pm 1.00$ relative humidity for six days.

\begin{tabular}{|c|c|c|c|c|c|c|c|c|c|c|}
\hline \multirow[t]{2}{*}{ Maturity degrees } & \multirow[t]{2}{*}{ Packages } & \multicolumn{8}{|c|}{ Storage period (days) } & \multirow{2}{*}{ Mean } \\
\hline & & \multicolumn{2}{|c|}{0} & \multicolumn{3}{|c|}{3} & \multicolumn{3}{|c|}{6} & \\
\hline & LDPE & 121.6 & $\begin{array}{ll}a & A\end{array}$ & 103.4 & $a$ & $A$ & 121.1 & $a$ & $A$ & 115.3 \\
\hline \multirow[t]{3}{*}{ Green } & PET & 121.6 & a $\mathrm{A}$ & 98.5 & $a b$ & $A B$ & 88.7 & $a b c$ & $B$ & 102.9 \\
\hline & EP-PVC & 121.6 & a $\mathrm{A}$ & 93.1 & $a b$ & $A$ & 104.9 & $a b$ & $A$ & 106.5 \\
\hline & LDPE & 105.4 & a $\mathrm{A}$ & 119.6 & $\mathrm{a}$ & $A$ & 72.0 & $\mathrm{bc}$ & B & 99.0 \\
\hline \multirow[t]{3}{*}{ Middle-mature } & PET & 105.4 & a $A$ & 86.7 & $a b$ & B & 53.4 & c & B & 81.8 \\
\hline & EP-PVC & 105.4 & a $\mathrm{A}$ & 67.7 & $b$ & B & 91.6 & $a b c$ & $A B$ & 86.9 \\
\hline & LDPE & 2.45 & b A & 0.98 & c & $A$ & 1.47 & c & $A$ & 1.63 \\
\hline \multirow[t]{2}{*}{ Mature } & PET & 2.45 & b $A$ & 0.98 & $\mathrm{a}$ & $A$ & 0.98 & c & $A$ & 1.96 \\
\hline & EP-PVC & 2.45 & b A & 2.45 & C & A & 0.98 & C & A & 1.47 \\
\hline
\end{tabular}

Mean

76.5

63.3

59.5

Means followed by the same letter, uppercase in the line and lowercase in the column, do not differ significantly from each other at $95 \%$ probability, by the Tukey test. LDPE: low density polyethylene package with lid. PET: polyethylene terephthalate package. EP-PVC: expanded polystyrene tray covered with $12 \mu \mathrm{m}$ polyvinyl chloride film.

In relation to ascorbic acid it was observed $259 \mathrm{mg}$ of ascorbic acid $100 \mathrm{~g}^{-1}$ of pulp in green fruits, $284.6 \mathrm{mg}$ of ascorbic acid $100 \mathrm{~g}^{-1}$ of pulp in middle-mature stage and $299.2 \mathrm{mg}$ of ascorbic acid $100 \mathrm{~g}^{-1}$ of pulp in mature (Fallen fruits) (Table 4). Similar contents were found by Carnelossi et al. (2004) in middle-mature $(274.7 \mathrm{mg}$ of ascorbic acid $100 \mathrm{~g}^{-1}$ of pulp) and mature mangaba fruits stage (252.7 mg of ascorbic acid $100 \mathrm{~g}^{-1}$ of pulp) harvested in Northeast region and Plácido et al. (2015) cited values of 133.07 and $232.48 \mathrm{mg}$ of ascorbic acid $100 \mathrm{~g}^{-1}$ of pulp for the same maturity degrees order in Brazilian Cerrado. Perfeito et al. (2015) also observed an increase in ascorbic acid content according tomangaba maturity degree produced in Brazilian Cerrado. However, the values were 34.5 and $56.1 \mathrm{mg}$ of ascorbic acid $100^{-1} \mathrm{~g}$ of pulp for middle-mature and mature stages, respectively.
Influence was detectedin storage period in relation to treatments $(p<0.01)$, with decrease contents at sixth day, except in middle-mature stage conditioned in EP-PVC, which maintained ascorbic acid values throughout the days, probably for maintaining fruits quality. Chitarraand Chitarra (2005) mentioned ascorbic acid levels tend to decrease with fruit maturation and storage due to direct action of ascorbic acid oxidase enzyme or oxidizing enzymes (peroxidase) action. Carnelossi et al. (2004) reported ascorbic acid levels might be used as quality loss indicative for mangaba fruit.

Ascorbic acid content was more conserved in middle-mature fruits reducing only $15 \%$ in LDPE package, $20.7 \%$ in PET and $1.8 \%$ in EP-PVC at the end of storage (Table 4). In the other hand, higher losses were noticed for green fruits: $56.2 \%$ (LDPE), $50 \%$ (PET) and 58.8\% (EP-PVC) and mature stage 43.5\% (LDPE), 41.1\% (PET) and 29.5\% (EP-PVC). 
Table 4. Mangaba ascorbic acid content (mg of ascorbic acid $100 \mathrm{~g}^{-1}$ of pulp), in three maturity degreesunder different modified atmospheres, storage at $3^{\circ} \mathrm{C} \pm 1.00$ and $80 \% \pm 1.00$ relative humidity for six days.

\begin{tabular}{|c|c|c|c|c|c|c|c|c|c|c|}
\hline \multirow[t]{3}{*}{ Maturitydegrees } & \multirow{3}{*}{$\begin{array}{l}\text { Packages } \\
\text { LDPE }\end{array}$} & \multicolumn{8}{|c|}{ Storageperiod (days) } & \multirow{3}{*}{$\begin{array}{l}\text { Mean } \\
187.7\end{array}$} \\
\hline & & \multicolumn{2}{|r|}{0} & \multicolumn{3}{|c|}{3} & \multicolumn{3}{|c|}{6} & \\
\hline & & 259.0 & a A & 190.9 & de & $B$ & 113.4 & c & $\mathrm{C}$ & \\
\hline \multirow[t]{3}{*}{ Green } & PET & 259.0 & a $A$ & 183.2 & de & B & 129.5 & c & B & 190.5 \\
\hline & EP-PVC & 259.0 & a $A$ & 168.9 & $\mathrm{e}$ & B & 107.4 & c & $\mathrm{C}$ & 178.4 \\
\hline & LDPE & 284.6 & a $B$ & 362.0 & $\mathrm{a}$ & A & 241.8 & $a b$ & B & 296.1 \\
\hline \multirow[t]{3}{*}{ Middle-mature } & PET & 284.6 & a $A$ & 306.6 & $a b$ & A & 225.5 & $a b$ & B & 272.2 \\
\hline & EP-PVC & 284.6 & a $A$ & 287.4 & $a b c$ & A & 279.4 & $a$ & $A$ & 283.8 \\
\hline & LDPE & 299.2 & a $A$ & 216.6 & cde & B & 169.1 & bc & B & 228.3 \\
\hline \multirow[t]{2}{*}{ Mature } & PET & 299.2 & b $A$ & 143.8 & $\mathrm{e}$ & B & 176.1 & $\mathrm{bc}$ & B & 206.4 \\
\hline & EP-PVC & 299.2 & a $A$ & 247.1 & $a b c$ & $A B$ & 211.0 & $a b$ & $\mathrm{~B}$ & 252.4 \\
\hline Mean & & & 80.9 & & 234.1 & & 183 & 3.6 & & \\
\hline
\end{tabular}

Means followed by the same letter, uppercase in the line and lowercase in the column, do not differ significantly from each other at $95 \%$ probability, by the Tukey test. LDPE: low density polyethylene package with lid. PET: polyethylene terephthalate package. EP-PVC: expanded polystyrene tray covered with $12 \mu \mathrm{m}$ polyvinyl chloride film.

In fruit characterization, there was an increase in soluble solids contents with maturation progression (Table 5), with the lowest values observed in green fruits $\left(11.7^{\circ} \mathrm{Brix}\right)$, the highest in mature fruits $\left(15.8^{\circ} \mathrm{Brix}\right)$ and intermediate values for middle-mature stage $\left(14.1^{\circ} \mathrm{Brix}\right)$. Chitarra and Chitarra (2005) pointed out thatsolublesolids increase occurs during fruit maturation due to sugars deterioration, reaching the maximum value at the end of ripening, conferring quality to the product. Similar contents were found by Carnelossi et al. (2004) in mangaba fruits: $15.2^{\circ}$ Brix and 13.1 ${ }^{\circ} \mathrm{Brix}$ in mature and middle-mature stages, respectively.
A significant difference was observed in soluble solids among treatments $(p<0.01)$, on third day of storage, mangabas conditioned in EP-PVC presented, in general, better conservation in contents and on sixth day green and middlemature in the same atmosphere. Soluble solids contents were also influenced by storage $(p<0.01)$, only in mature treatment in EP-PVC provided the greatest increase in contents, about $15.8 \%$ at sixth day of storage. Soares Junior et al. (2008) researching mangaba fruit cited soluble solids increase during shelf-life and justified this behaviour because of fruits ripening.

Table 5. Mangabasoluble solids content ( ${ }^{\circ}$ Brix), in three maturity degreesunder different modified atmospheres, storage at $3^{\circ} \mathrm{C} \pm 1.00$ and $80 \% \pm 1.00$ relative humidity for six days.

\begin{tabular}{|c|c|c|c|c|c|c|c|c|c|c|c|}
\hline \multirow[t]{2}{*}{ Maturity degrees } & \multirow[t]{2}{*}{ Packages } & \multicolumn{9}{|c|}{ Storage period (days) } & \multirow{2}{*}{ Mean } \\
\hline & & \multicolumn{3}{|c|}{0} & \multicolumn{3}{|c|}{3} & \multicolumn{3}{|c|}{6} & \\
\hline \multirow[t]{3}{*}{ Green } & LDPE & 11.7 & b & A & 12.5 & $\mathrm{~cd}$ & A & $12.4 \mathrm{cdA}$ & $\mathrm{cd}$ & A & 12.2 \\
\hline & PET & 11.7 & $\mathrm{~b}$ & A & 12.5 & $\mathrm{~cd}$ & A & $12.7 \mathrm{cdA}$ & $\mathrm{cd}$ & A & 12.3 \\
\hline & EP-PVC & 11.7 & b & A & 11.2 & $d$ & A & $10.5 \mathrm{dA}$ & d & A & 11.1 \\
\hline \multirow[t]{3}{*}{ Middle-mature } & LDPE & 14.1 & $a b$ & A & 15.9 & a & A & $14.7 \mathrm{bcA}$ & bc & A & 14.9 \\
\hline & PET & 14.1 & $a b$ & A & 15.1 & $a b c$ & A & $14.0 \mathrm{bcA}$ & bc & A & 14.4 \\
\hline & EP-PVC & 14.1 & $a b$ & A & 14.9 & $a b c$ & A & $13.3 \mathrm{bcdA}$ & bcd & A & 14.1 \\
\hline \multirow[t]{3}{*}{ Mature } & LDPE & 15.8 & a & A & 15.8 & $a b$ & A & $15.2 \mathrm{bcA}$ & bc & A & 15.6 \\
\hline & PET & 15.8 & $\mathrm{a}$ & A & 14.5 & $a b c$ & A & $16.0 \mathrm{abA}$ & $a b$ & A & 15.4 \\
\hline & EP-PVC & 15.8 & $\mathrm{a}$ & B & 12.8 & bcd & C & $18.3 \mathrm{aA}$ & $a$ & A & 15.6 \\
\hline Mean & & \multicolumn{3}{|c|}{13.9} & & \multicolumn{2}{|l|}{13.9} & \multicolumn{3}{|c|}{14.1} & \\
\hline
\end{tabular}

Means followed by the same letter, uppercase in the line and lowercase in the column, do not differ significantly from each other at $95 \%$ probability, by the Tukey test. LDPE: low density polyethylene package with lid. PET: polyethylene terephthalate package. EP-PVC: expanded polystyrene tray covered with $12 \mu \mathrm{m}$ polyvinyl chloride film.

In relation to titratable acidity (Table 6 ), the highest levels were observed in green fruits (1.64 g of citric acid $100 \mathrm{~g}^{-1}$ of pulp) statistically different from middle-mature fruits (1.01 g of citric acid $100 \mathrm{~g}^{-1}$ of pulp) and mature stage $(0.79 \mathrm{~g}$ of citric acid $100 \mathrm{~g}^{-1}$ of pulp), at assembly experiment time. 
Titratable acidity contents were influenced by treatments $(p<0.01)$ and by storage period $(p<0.01)$, with organic acids content decreasing until sixth day with levels of 0.62 to $0.91 \mathrm{~g}$ of citric acid $100 \mathrm{~g}^{-1}$ of pulp.

Fruits packed in EP-PET presented the lowest contents at sixth day of storage $(0.62 \mathrm{~g}$ of citric acid $100 \mathrm{~g}^{-1}$ of pulp) in relation to other treatments. However, it was observed that green fruits conditioned in all atmospheres lost $48.3 \%$ of acidity on average in shelf-life and smaller losses were perceived in middle-mature (13.6\%) and mature fruits (7.5\%). Chitarra and Chitarra (2005) justify that fruits acids content decreases with maturation, as they are used like respiration substrate or transformed into sugars, presenting important role in flavour and aroma.

Table 6. Mangaba titratable acidity content (g of citric acid $100 \mathrm{~g}^{-1}$ of pulp), in three maturity degreesunder different modified atmospheres, storage at $3^{\circ} \mathrm{C} \pm 1.00$ and $80 \% \pm 1.00$ relative humidity for six days.

\begin{tabular}{|c|c|c|c|c|c|c|c|c|c|c|}
\hline \multirow{2}{*}{ Maturity degrees } & \multirow[t]{2}{*}{ Packages } & \multicolumn{8}{|c|}{ Storage period (days) } & \multirow{2}{*}{ Mean } \\
\hline & & \multicolumn{2}{|r|}{0} & \multicolumn{3}{|c|}{3} & \multicolumn{3}{|l|}{6} & \\
\hline & LDPE & 1.64 & a $A$ & 0.88 & $a$ & B & 0.86 & a & B & 1.12 \\
\hline \multirow{3}{*}{ Green } & PET & 1.64 & a $A$ & 0.76 & $a b c$ & B & 0.85 & a & B & 1.08 \\
\hline & EP-PVC & 1.64 & a $\mathrm{A}$ & 0.87 & $a$ & B & 0.83 & a & B & 1.11 \\
\hline & LDPE & 1.02 & b A & 0.86 & $\mathrm{a}$ & B & 0.88 & a & B & 0.92 \\
\hline \multirow[t]{3}{*}{ Middle-mature } & PET & 1.02 & b $A$ & 0.77 & $a b c$ & $\mathrm{C}$ & 0.91 & a & B & 0.90 \\
\hline & EP-PVC & 1.02 & b A & 0.80 & $a b$ & B & 0.84 & a & B & 0.89 \\
\hline & LDPE & 0.79 & C $A$ & 0.64 & $\mathrm{~cd}$ & B & 0.79 & a & A & 0.74 \\
\hline \multirow[t]{2}{*}{ Mature } & PET & 0.79 & C A & 0.71 & bcd & $A B$ & 0.62 & b & B & 0.70 \\
\hline & EP-PVC & 0.79 & C A & 0.59 & d & $\mathrm{B}$ & 0.78 & a 1 & A & 0.72 \\
\hline Mean & & & 1.15 & & 0.76 & & 0.81 & & & \\
\hline
\end{tabular}

Means followed by the same letter, uppercase in the line and lowercase in the column, do not differ significantly from each other at $95 \%$ probability, by the Tukey test. LDPE: low density polyethylene package with lid. PET: polyethylene terephthalate package. EP-PVC: expanded polystyrene tray covered with $12 \mu \mathrm{m}$ polyvinyl chloride film.

In maturation index (MI) there was significant difference $(p<0.01)$, the highest values were observed in mature fruits (20.0) followed by middle-mature (13.0) and green (6.98) at assembly experiment time. SS/TA ratio is the most used method for flavour evaluation, being more representative than independent analysis of carbohydrates or organic acids (CHITARRA; CHITARRA, 2005).

$\mathrm{MI}$ values were influenced by treatment and the storage $(p<0.01)$, except in mature treatment in EP-PVC $(p>0.05)$. A tendency to increase the values at sixth day of storage was observed, varying from 12.6 to 25.7. However, it is observed that the green fruits increased the indexes by $102 \%$ average, indicating a higher ripening speed, while in middle-mature stage presented percentages of 28.5\% (LDPE), 18.5 (PET) and $20.7 \%$ (EP-PVC). 
Table 7.Mangaba maturity index (SS/AT), in three maturity degreesunder different modified atmospheres, storage at $3^{\circ} \mathrm{C} \pm 1.00$ and $80 \% \pm 1.00$ relative humidity for six days.

\begin{tabular}{|c|c|c|c|c|c|c|c|c|c|}
\hline \multirow[t]{2}{*}{ Maturity degrees } & \multirow[t]{2}{*}{ Packages } & \multicolumn{7}{|c|}{ Storage period (days) } & \multirow{3}{*}{$\begin{array}{r}\text { Mean } \\
11.8\end{array}$} \\
\hline & & \multicolumn{2}{|r|}{0} & \multicolumn{2}{|c|}{3} & \multicolumn{3}{|c|}{6} & \\
\hline & LDPE & 6.98 & $\begin{array}{ll}C & B\end{array}$ & $14.1 \mathrm{de}$ & $A$ & 14.5 & $\mathrm{~cd}$ & $A$ & \\
\hline \multirow[t]{3}{*}{ Green } & PET & 6.98 & C $B$ & 16.3 cde & $A$ & 15.3 & $c d$ & $A$ & 12.8 \\
\hline & EP-PVC & 6.98 & C B & $12.9 \mathrm{e}$ & $A$ & 12.6 & $d$ & $A$ & 10.8 \\
\hline & LDPE & 13.0 & b $B$ & $18.4 \mathrm{bcd}$ & $A$ & 16.7 & $\mathrm{~cd}$ & $A B$ & 16.1 \\
\hline \multirow[t]{3}{*}{ Middle-mature } & PET & 13.0 & b $B$ & $19.5 \mathrm{abc}$ & $A$ & 15.4 & $c d$ & B & 16.0 \\
\hline & EP-PVC & 13.0 & $b \quad B$ & $18.6 \mathrm{bcd}$ & $A$ & 15.7 & $c d$ & $A B$ & 15.8 \\
\hline & LDPE & 20.0 & a $B$ & 24.4 a & $A$ & 19.2 & bc & B & 21.2 \\
\hline \multirow[t]{2}{*}{ Mature } & PET & 20.0 & a $B$ & $20.4 a b c$ & B & 25.7 & a & $A$ & 22.0 \\
\hline & EP-PVC & 20.0 & a $\mathrm{A}$ & $21.7 \mathrm{ab}$ & $A$ & 23.3 & $a b$ & $A$ & 21.6 \\
\hline
\end{tabular}

Means followed by the same letter, uppercase in the line and lowercase in the column, do not differ significantly from each other at $95 \%$ probability, by the Tukey test. LDPE: low density polyethylene package with lid. PET: polyethylene terephthalate package. EP-PVC: expanded polystyrene tray covered with $12 \mu \mathrm{m}$ polyvinyl chloride film.

The $\mathrm{pH}$ varied as maturation stage function. Green fruits presented $\mathrm{pH} 3.84$, middlemature $\mathrm{pH} 3.87$ and mature $\mathrm{pH}$ 4.07. Nascimento, Cardoso and Cocozza (2014), characterizing mature mangaba fruits in West region of Bahia found values of 3.45 to 4.39 , similar to the present study. Although, Perfeito et al. (2015) presented $\mathrm{pH}$ 3.47in green fruits, $\mathrm{pH} 3.79$ in middle-mature and $\mathrm{pH} 3.97$ in mature stage.

In the other hand, lower values were cited by Carnelossi et al. (2004), about 3.5 for middlemature and mature stages. Souza et al. (2007) observed $\mathrm{pH}$ values ranging from 2.58 to 3.17 in fruits harvested at physiological maturity.

Treatment has been influenced by $\mathrm{pH}$ $(p<0.01)$ and storage $(p<0.01)$. Among treatments, a larger value was observed in mature fruits in PET (4.07), not statistically different from LDPE (4.01), PVC (3.96) and green stage in LDPE (3.84). The $\mathrm{pH}$ values increase with acidity reduction indicating maturation (CHITARRA; CHITARRA, 2005).

During storage period, there was statistical difference between $\mathrm{pH}$ values $(\mathrm{p}<0.01)$, at assembly experiment time mean value was 3.93 , decreasing on third day to 3.8 and returning to 3.93 on the sixth day.Opposite result was found by Carnelossi et al. (2004), who observed increased $\mathrm{pH}$ values in mangaba fruits stored at $25{ }^{\circ} \mathrm{Cand}$ during storage, Silva et al. (2013) reported decreases in $\mathrm{pH}$ values in middle-mature fruits.

Table 8. Mangaba $\mathrm{pH}$ values, in three maturity degrees under different modified atmospheres, storage at $3^{\circ} \mathrm{C}$ \pm 1.00 and $80 \% \pm 1.00$ relative humidity for six days.

\begin{tabular}{llcccc}
\hline Maturity degrees & Packages & \multicolumn{3}{c}{ Storage period (days) } & \multirow{2}{*}{ Mean } \\
\cline { 3 - 5 } Green & & 0 & 3 & 6 & $3.84 \mathrm{ab}$ \\
& LDPE & 3.84 & 3.79 & 3.89 & $3.79 \mathrm{~b}$ \\
\multirow{4}{*}{ Middle-mature } & PET & 3.84 & 3.65 & 3.89 & $3.84 \mathrm{~b}$ \\
& EP-PVC & 3.84 & 3.78 & 3.89 & $3.81 \mathrm{~b}$ \\
& LDPE & 3.87 & 3.68 & 3.87 & $3.84 \mathrm{~b}$ \\
Mature & PET & 3.87 & 3.84 & 3.81 & $3.82 \mathrm{~b}$ \\
& EP-PVC & 3.87 & 3.73 & 3.88 & $4.01 \mathrm{ab}$ \\
& LDPE & 4.07 & 3.85 & 4.11 & $4.07 \mathrm{ab}$ \\
Mean & PET & 4.07 & 3.94 & 4.22 & $3.96 \mathrm{ab}$ \\
\hline
\end{tabular}

Means followed by the same letter, uppercase in the line and lowercase in the column, do not differ significantly from each other at $95 \%$ probability, by the Tukey test. LDPE: low density polyethylene package with lid. PET: polyethylene terephthalate package. EP-PVC: expanded polystyrene tray covered with $12 \mu \mathrm{m}$ polyvinyl chloride film.

In reducing sugar contents reported in Table 9, mangaba fruits were influenced by maturation stage, and presented the highest values in mature fruits (3.97\%), followed bygreen 
(1.54\%) and middle-mature (1.37\%). In fruits, the main sugars are reducers, especially glucose. During ripening, there is an increase in content of these simple sugars until complete maturation accompanied byacidity reduction. This is due to long-chain carbohydrateshydrolysis and consequent increase in sucrose, fructose and glucose contents (CHITARRA; CHITARRA, 2005; OLIVEIRA et al., 2001).

Souza et al. (2007) observed in 10 mangaba clones, at physiological maturation stage, levels from $6.6 \%$ to $11.05 \%$ for reducing sugar, higher than found in the present study. According to Fagundes and Yamanishi (2001), quality attributes are influenced by climatic conditions, precipitation, soil, cultivar, temperature, season and harvest site, which could explain these differences with the mentioned literature.

The reduction sugar content was influenced by treatments and storage $(p<0.01)$, there was statistical difference in green mangabas in PET;middle-mature in LDPE;mature in LDPE, PET and EP-PVC, with an increase of $23.4 \%, 42.4 \%$, $2.0 \%, 5.0 \%$ and $15.4 \%$ on sixth day of storage showing higher ripening speed in these atmospheres. Silva et al. (2016) reported that levels of reducing sugar in atemoya increased during shelf-life, with or without using LDPE.

Table 9. Mangaba reducing sugars contents (\%), in three maturity degreesunder different modified atmospheres, storage at $3^{\circ} \mathrm{C} \pm 1.00$ and $80 \% \pm 1.00$ relative humidity for six days.

\begin{tabular}{|c|c|c|c|c|c|c|c|c|c|}
\hline \multirow[t]{2}{*}{ Maturity degrees } & \multirow[t]{2}{*}{ Packages } & \multicolumn{7}{|c|}{ Storage period (days) } & \multirow{2}{*}{ - Mean } \\
\hline & & \multicolumn{2}{|c|}{0} & \multicolumn{2}{|r|}{3} & \multicolumn{3}{|c|}{6} & \\
\hline & LDPE & 1.54 & b $A$ & 1.58 & C A & 1.83 & $\mathrm{c}$ & $A$ & 1.65 \\
\hline \multirow{3}{*}{ Green } & PET & 1.54 & b $B$ & 1.66 & C A & 1.90 & c & A & 1.70 \\
\hline & EP-PVC & 1.54 & b A & 1.57 & C A & 1.78 & c & A & 1.63 \\
\hline & LDPE & 1.32 & $b \quad B$ & 1.61 & C A & 1.88 & c & $A$ & 1.60 \\
\hline \multirow[t]{3}{*}{ Middle-mature } & PET & 1.32 & b A & 1.33 & C $A$ & 1.55 & c & $A$ & 1.40 \\
\hline & EP-PVC & 1.32 & b A & 1.51 & C $A$ & 1.56 & c & $A$ & 1.46 \\
\hline & LDPE & 3.97 & a $\quad A B$ & 3.69 & a $B$ & 4.05 & $\mathrm{~b}$ & A & 3.90 \\
\hline \multirow[t]{2}{*}{ Mature } & PET & 3.97 & a $A$ & 2.51 & $b \quad B$ & 4.17 & $a b$ & $A$ & 3.55 \\
\hline & EP-PVC & 3.97 & a $B$ & 3.92 & a $B$ & 4.58 & $\mathrm{a}$ & A & 4.16 \\
\hline
\end{tabular}

Means followed by the same letter, uppercase in the line and lowercase in the column, do not differ significantly from each other at $95 \%$ probability, by the Tukey test. LDPE: low density polyethylene package with lid. PET: polyethylene terephthalate package. EP-PVC: expanded polystyrene tray covered with $12 \mu \mathrm{m}$ polyvinyl chloride film.

\section{CONCLUSIONS}

Falling (mature) mangabas limited storage period in six days, regardless modified atmosphere used, presenting greater mass loss, reducing sugar content and less firmness. These fruits must be destined to processing, in order to add value to the product.

Mangabas harvested in middle-mature stage conditioned in EP-PVC stored storage at $3^{\circ} \mathrm{C}$ \pm 1.00 and $80 \% \pm 1.00$ relative humidity for six days maintain acceptable ascorbic acid contents.

\section{ACKNOWLEDGMENT}

To Fundação de Amparo à Pesquisa do Estado de São Paulo (FAPESP) for supportgrantedtoworkachievement.

\section{REFERENCES}

ALMEIDA, M. M. B.; SOUSA, P. H. M.; ARRIAGA, A. M. C.; PRADO, G. M.; MAGALHÃES, C. E. C.; MAIA, G. A.; LEMOS, T. L. G. Bioactive compounds and antioxidant activity of fresh exotic fruits from northeastern Brazil.Food Research International, Darking, v.44, n.7, p.2155-2149, 2011.https://doi.org/10.1016/j.foodres.2011.03.0 51

CAMPOS, R. P.; KNOCH, B. HIANE, P. A.; RAMOS, M. I. L.; RAMOS FILHO, M. M. 1-MCP em Mangabas armazenadas em temperatura ambiente e a $11^{\circ} \mathrm{C}$. Revista Brasileira de Fruticultura, Jaboticabal, v. 33, n. spe1, p. 206212, 2011. http://dx.doi.org/10.1590/S010029452011000500024

CARNELOSSI, M. A. G.; TOLEDO, W. F. F.; SOUZA, D. C. L.; LIRA, M. L.; SILVA, G. F.; JALALI, V. R. R.; VIÉGAS, P. R. A. Conservação pós-colheita de mangaba (Hancorniaspeciosa Gomes). Ciência e Agrotecnologia, Lavras, v. 28, n. 5, p. 1119-1125, 2004.http://dx.doi.org/10.1590/S1413$\underline{70542004000500021}$ 
CARNELOSSI, M. A. G.; SENA, H. C.; NARAIN, N.; YAGUIU, P.; SILVA, G. F. Physico-Chemical Quality Changes in Mangaba (Hancorniaspeciosa Gomes) Fruit Stored at Different Temperatures. Brazilian Archives of Biology and Technology, Curitiba, v. 52 $\mathrm{n}$. 4, p. 985-990,

2009.http://dx.doi.org/10.1590/S151689132009000400023

CHITARRA, M. I. F.; CHITARRA, A. B. Pós-colheita de frutas e hortaliças: fisiologia e manuseio. Lavras: UFLA, 2005.783p.

DREHMER, A. M. F.; AMARANTE, C. V. T. Conservação pós-colheita de frutos de araçávermelho em função do estádio de maturação e temperatura de armazenamento. Revista Brasileira de Fruticultura, Jaboticabal, v. 30, n. 2, p.

322-

326, 2008.http://dx.doi.org/10.1590/S010029452008000200009

FAGUNDES, G. R.; YAMANISHI, O. K. Características físicas e químicas de frutos de mamoeiro do grupo solo comercializado em 4 estabelecimentos de Brasília DF. Revista Brasileira de Fruticultura, Jaboticabal, v.23, n. 3, p.541-545, 2001.http://dx.doi.org/10.1590/S0100-

29452001000300018

FIGUEIREDO NETO, A.; OLIVIER, N. C.; ROJAS, A. B. G.; SILVA, J. C.; PADILHA, C. Avaliação pós-colheita de mamão variedade Formosa submetido a danos mecânicos e ensaios de compressão durante o armazenamento. Revista Ciências Técnicas Agropecuárias, San José de las Lajas, v. 22, n. 2, p. $5-10,2013$.

INSTITUTO ADOLFO LUTZ. Normas analíticas do Instituto Adolfo Lutz. I - Métodos químicos e físicos para análise de alimentos. 3.ed. São Paulo, 1985. 533p.

LEDERMAN, I. E.; SILVA JUNIOR, J. F.; BEZERRA, J. E. F.; ESPÍNDOLA, A. C. M. Mangaba (Hancorniaspeciosa Gomes). Jaboticabal: FUNEP, 2000. 35p.

MOURA, F. T. Fisiologia da maturação e conservação pós-colheita de mangaba (Hancorniaspeciosa Gomes). 2005. $148 \mathrm{f}$. Dissertação (Mestrado em Agronomia)- Faculdade de Agronomia, Universidade Federal da Paraíba, Areia, 2005.
NARAIN, N.; FERREIRA, D. Tecnologia de alimentos aplicada à mangaba. In: Simpósio brasileiro sobre a cultura da mangaba, 1., 2003, Aracajú. Anais... Aracajú: Embrapa Tabuleiros Costeiros, 1CD-ROM.

NASCIMENTO, R. S. M.; CARDOSO, J. A.; COCOZZA, F. D. Caracterização física e físico-química de frutos de mangabeira (Hancorniaspeciosa Gomes) no oeste da Bahia. Revista Brasileira de Engenharia Agrícola e Ambiental, Campina Grande, v.18, n.8, p.856-860, 2014.http://dx.doi.org/10.1590/18071929

OLIVEIRA, M. A.; CEREDA, M. P.; CABELlO, C.; URBANO, L. H.Quantificação de açúcares em pêssegos da variedade Biuti, armazenados sob condições de ambiente e refrigeração. Revista Brasileira de Fruticultura, Jaboticabal, v. 23, n. 2, p.

424-427,

2001.http://dx.doi.org/10.1590/S010029452001000200046

PEREIRA, A. V.; PEREIRA, E. B. C.; SILVA JÚNIOR, J. F.; SILVA, D. B. Mangaba. In: Frutas nativas da região Centro- Oeste do Brasil. Brasília: Embrapa Informação Tecnológica, 2006, p. 322.

PERFEITO, D. G. A.; CARVALHO, N.;LOPES, M. C. M.; SCHMIDT, F. L. Caracterização de frutos de mangabas (Hancorniaspeciosa Gomes) e estudo de processos de extração da polpa. Revista de Agricultura Neotropical, Cassilândia, v. 2, n. 3, p. $1-7,2015$

PIMENTEL GOMES, F. Curso de estatística experimental. 15. ed. Piracicaba: FEALQ, 2009. 451p.

PLÁCIDO, G. R.; SILVA, R. M.; CAGNIN, C.; SILVA, M. A. P.; SOARES, J. C.; CALIARI, M. Use of pectin in the storage of mangaba fruits (Hancorniaspeciosa Gomes) associated with refrigeration. African Journal of Biotechnology, Kenya, v. 14, n. 39, p. 2786-2799,

2015.http://dx.doi.org/10.5897/AJB2015.14526

SANTOS, A. F.; SILVA, S. M.; MENDINÇA, R. M. N.; ALVES, R. E. Conservação pós-colheita de mangaba em função da maturação, atmosfera e temperatura de armazenamento.Ciência e Tecnologia de Alimentos, Campinas, v.29, n.1 p. 85-91, 2009. 
SILVA JUNIOR, J. F. A cultura da mangaba. Revista Brasileira Fruticultura, Jaboticabal, v. 26, n. 1, p. i, 2004.

SILVA, A. V. C.; YAGUIU, P.; MUNIZ, E. N.; VITÓRIA, M. F.; AMORIM, J. A. E. Vida útil de mangaba colhida em dois estádios de maturação.Aracaju: Embrapa Tabuleiros Costeiros, 2013. 15 p.

SILVA, C. G. M.; SILVA, M. P. S.; BIAZATTI, M. A.; SANTOS, P. C.; SILVA, N. M.; MIZOBUTSI, G. P. Uso do 1-MCP e atmosfera modificada na pós-colheita de atemoia 'Gefner'. Revista Brasileira de Ciências Agrárias, Recife, v. 11, n. 2, 2016, p. 67-72, 2016.http://dx.doi.org/10.5039/agraria.v11i2a536 $\underline{5}$

SIMÓN, A.; GONZÁLEZ-FANDOS, E.; RODRÍGUEZ, D. Effect of film and temperature on the sensory, microbiological and nutritional quality of minimally processed cauliflower.International Journal of Food Science and Technology, London, v. 43, n. 9, p. 1628-1636,

2008.https://doi.org/10.1111/j.1365-

2621.2007.01672.x

SOARES JUNIOR, M. S.; CALIARI, M.; VERA, R.; SOUZA, A. G. Conservação pós-colheita de mangaba sob refrigeração e modificação da atmosfera de armazenamento. Pesquisa Agropecuária Tropical, Goiânia, v. 38, n. 2, p. 7886, 2008.

SOUZA, F. G.; FIGUEIREDO, R. W.; ALVES, R. E.; MAIA, G. A.;ARAÚJO, I. A. Qualidade pós-colheita de frutos de diferentes clones de mangabeira (Hancorniaspeciosa Gomes). Ciência e Agrotecnologia, Lavras, v. 31, n. 5, p. 1449-1454, 2007.http://dx.doi.org/10.1590/S1413$\underline{70542007000500027}$

STEFFENS, C. A.; AMARANTE, C. V. T.; ALVES, E. O.; TANAKA, $\mathrm{H}$; BRACKMANN, A.; BOTH, V.. Armazenamento de ameixas 'Laetitia' em atmosfera modificada.Ciência Rural, Santa Maria, $\begin{array}{llll}\text { v. } 39, \quad \text { v. } & 9 \text {, } & \text { p.2439-2444, }\end{array}$ 2009. http://dx.doi.org/10.1590/S0103$\underline{84782009000900009}$

VIEIRA, R. F.; AGOSTINI-COSTA, T. S.; SILVA, D. B.; SANO, S. M.; FERREIRA, F. R. Frutas nativas da região Centro- oeste do Brasil. Brasília: Embrapa Informação Tecnológica, 2010. 322p.

VIEITES, R. L.; RUSSO, V. C.; DAIUTO, E. R. Qualidade do abacate 'Hass' frigoarmazenado submetido a atmosferas modificadas ativas. Revista Brasileira de Fruticultura, Jaboticabal, v.36, n. 2, p.329-338, 20014.http://dx.doi.org/10.1590/0100-2945$162 / 13$

Recebido para publicação em 26/04/2018 Revisado em 04/07/2018 Aceito em 05/07/2018 